\title{
Childhood Inmigration and Obesity - An Emerging Problem
}

\author{
I. Díez López ${ }^{1}$ and M. Carranza Ferrer ${ }^{2}$ \\ ${ }_{1}$ Pediatric Endocrinology Unit, Txagorritxu Hospital, HUA, \\ ${ }_{2}^{2}$ Pediatric Endocrinology Unit, Nuestra Señora de Meritxell Hospital, \\ 1Spain \\ ${ }^{2}$ Andorra
}

\section{Introduction}

Overweight and obesity are rapidly increasing among children and adults. In 1998, the World Health Organisation recognized obesity as a major worldwide public health epidemic [1].

In the World Health conference at Geneva called for specific action to halt this epidemic [2]. Overweight and obesity can lead to a wide array of health and social consequences. Childhood overweight appears to be associated with cardiovascular risk factors such a high blood pressure; hyperlipidemia, elevated insulin levels [3] and non-insulin-dependent diabetes mellitus (type 2 diabetes). Other comorbidities include asthma and orthopedic problems as well as a varity of more rare disorders [3,4]. Ultimately overweight in childhood is associated with premature mortality especially if combined with intrauterine growth retardation (small for gestacional age SGA). The psychological well-being and the quality of life can also be affected $[3,5,6]$.

Furthermore overweight and obesity in childhood, particularly in adolescence tends to persist into adulthood. The risk of adult overweight is about twofold increased for individuals who were overweight as children compared with individuals who were not overweight $[7,8]$. Adulthood overweight are at increased risk of dyslipidaemia, hypertension and type 2 diabetes even if the extra weight was lost during adulthood [6]. Psychological consequences include social and psychological stress, with increased risk of negative self- esteem, social isolation and negative influence on the career and family incomes [7].

There are wide geographical variations of overweight. Comparing reported prevalences of childhood overweight in Europe, Lobstein et al. [9] point out that children residing in central and Eastern Europe have a lower level of overweight than children from other parts of Europe, especially from Southern Europe. Average prevalences in Eastern Europe range from $10 \%$ to $18 \%$ among children aged 7 to 11 years, whereas values around $20 \%$ to $35 \%$ have been reported from countries like Greece and Spain $[9,10]$. It is suggested that the low obesity prevalence in Eastern Europe is a consequence of the huge economic burden and the associated poverty following the political transition in the 1990s. 


\section{A new reality, a new global illness: Obesity in children}

Studies in industrialized countries show that children from families with lower socioeconomic status particularly suffer from excess weight $[11,12]$. In less industrialized societies excess weight is found predominantly among children from families with higher socioeconomic status [9].

The process of migration, with its economic, social and environmental consequences may also affect health and body weight among migrants. Several US studies show differences in body mass index (BMI) among ethnic minorities $[13,14]$ but empirical data on BMI in children among different ethnic groups in Europe are scarce. In Europe children from nonEurope ethnic groups nowadays make up a large percentage of children overall, more in countries such us Spain, Italy.... In some cities up to $50 \%$ of all children entering school may be first, second or third generation migrants [15]. There are several studies or health reports on overweight and obesity among migrant children at school entry [16-19]. Migrant children were consistently found to be more frequently overweight. Obesity was noted as a particular problem among children of Turkish origin [20].

However, since the assessment of migration status is not uniform, comparisons between studies are difficult. In addition, family socioeconomic status and duration of migration are not routinely evaluated. It will be important investigated the prevalence of overweight and obesity among migrant and not migrant children at school entry and to assess the influence of duration of migration and socioeconomic status on overweight and obesity in childhood.

We can found in papers same examples about this fact: among boys in Bavaria, Kalies [21] found that the frequency of overweight and obesity in non-German compared to German children was 1.9 times higher for overweight and 2.4 times higher for obesity.

Results of one study that our city demonstrated in our city in Spain the obesity was more important and prevalence in children from Latino-America and East-Europe than not migrant [22]. We conclude that immigrant's children have a higher rate of obesity; their obesity was more severe, leave to assists to the consult with more frequency and get poor results losing BMI than Spanish children. Difficulties with language, different culture and the lack of perception of illness in the problem of obesity make this collective more vulnerable for obesity.

But the choice of reference and the definition of migrant status (see below) may also contribute to the slightly different results. In Europe, only a few studies on Body Mass Index (BMI) examined the potential impact of ethnicity or migration status on overweight and obesity. In a UK survey [23] showed that Indian and Pakistani boys had a higher prevalence of overweight compared with boys in the general.

UK population while Bangladeshi and Chinese boys had a lower overweight prevalence. Among girls, Afro-Caribbean and Pakistani girls more frequently were overweight while Indian and Chinese girls had a lower overweight prevalence compared to girls from the general population.

In our study the obesity was more prevalence in children from Latino-america and EastEurope than not migrant [22]. In France, the children of Maghrebian immigrants were more obese than French children in cross-sectional surveys conducted in the 1970ies and the 1990ies [30]. The overall prevalence of obesity increased from $8 \%$ to $13 \%$ over this period. Data from health surveys in 1992/93 and 1993/94 among children in the Netherlands showed that the average body mass index was higher among Turkish and Moroccan children than among Dutch children [24]. 
Geographical differences in overweight in Europe were demonstrated by Lobstein et al. [9]. Children from countries in Central and East Europe generally showed a low prevalence of overweight. On the other hand, a higher prevalence of overweight was found in children in Southern European countries. Recent data from Edirne in Turkey demonstrate comparatively low prevalences of overweight and obesity among adolescents $[25,26]$.

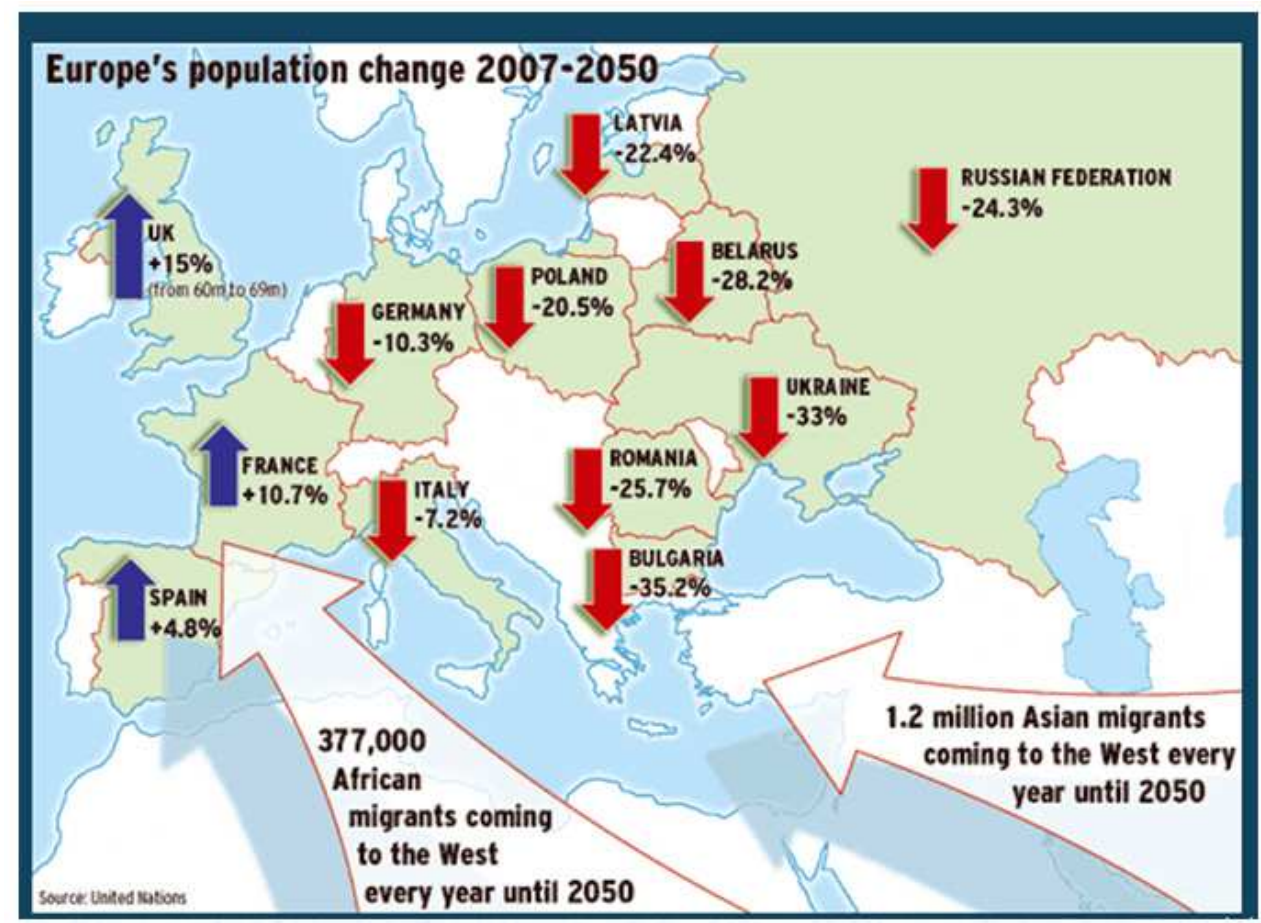

\section{2008 STRATEGIC FORECASTING}

\section{Other considerations}

The international variability of definitions concerning paediatric overweight and obesity implies methodological difficulties when comparing prevalences internationally. In adults, the BMI cut-points of 25 and 30 are widely used to define overweight and obesity. Unlike in adults, BMI in children varies substantially by age and gender during childhood and adolescence. Unfortunately no commonly accepted standard has yet emerged. Different reference systems have been proposed, so it is very difficult compare different studies of obesity in children.

It appears disputable whether the use of national reference data is preferable when assessing overweight and obesity among migrant children. The comparison to reference curves from the country of origin would disregard the environmental changes associated with migration in many instances. An international standard appeared the most suitable option in this situation (migrant children). 
Additional indexes of social class, social capital, or social context are rarely obtained in research surveys on diets and health. Undoubtedly, the arbitrary choice of cut-points and other problems associated with BMI-based classification systems in childhood will require further debate [27-28].

An association of overweight among migrant children with a long duration stay in Europe has not been reported previously. Social and political circumstances as potential explanation needs to be considered. The possible impact of such changes, however in opposite direction, can be more clearly seen in data from Russia. The prevalence of overweight in Russia decreased from $26.4 \%$ in 1992 to $10.2 \%$ in 1998 in 6-9 y-old children [35] and the prevalence of underweight in children rose during same time [9]. Economical recession during this time plausible explanation of this finding. In Poland, Koziel al. found a slightly decreasing trend in overweight between 1987 and 1997 in 14y-old boys [27].

In general, studies on socioeconomic status and overweight suggest that overweight is more prevalent among children of low income families in developed countries.

In contrast, the vast majority of studies in developing countries show a positive relationship between socioeconomic status and obesity among children [9,28].

In other fact, Race/ethnicity may have underlying genetic components; however, selfidentified race/ethnicity is complicated by genetic admixture [29]. Whether genetic differences across populations are associated with obesity development also remains unclear. A "thrifty genotype" may confer an advantage in an energy-poor environment, which would become disadvantageous in an energy-dense environment because it would predispose to increased accumulation of adipose tissue. The genes or gene variants that would support this hypothesis have not been identified.

One possible contributor to racial/ethnic disparities in the metabolic comorbidities of obesity may be related to different patterns of fat distribution. African American adults and children have less visceral and hepatic fat than white and Hispanic individuals $(22,28)$. Another possibility is that there are fundamental metabolic differences by race or ethnicity. Racial and ethnic differences in resting metabolic rate have been found (28) but may partly be due to differences in fat-free mass or organ mass and have not been shown to account for weight gain over time within populations (28) Some differences in insulin secretion and response among racial/ethnic groups have been found. African American and Hispanic children have lower insulin sensitivity than white children. African Americans have higher circulating insulin levels than whites, due to not only a more robust $\beta$-cell response to glucose but also decreased clearance of insulin in the liver. Hispanics also have lower insulin sensitivity than whites, after controlling for BMI and body composition, and have higher insulin levels in compensation for their relative insulin resistance (29).

There are differences in lipids and lipoproteins related to race/ethnicity (30). African Americans have lower rates of basal lipolysis than whites (30). This could be a metabolic risk factor for both the development of obesity and the risk of obesity-related comorbidities. African Americans also have lower levels of adiponectin than white subjects during childhood and adolescence, which may help explain their increased risk of diabetes and cardiovascular disease despite having less visceral adiposity (30). In summary, there is circumstantial evidence for biological differences in obesity development and the occurrence of comorbidities by race/ethnicity; however, the relationships are far from definitive (22). 


\section{Immigrants in Europe by region of origin 2005}

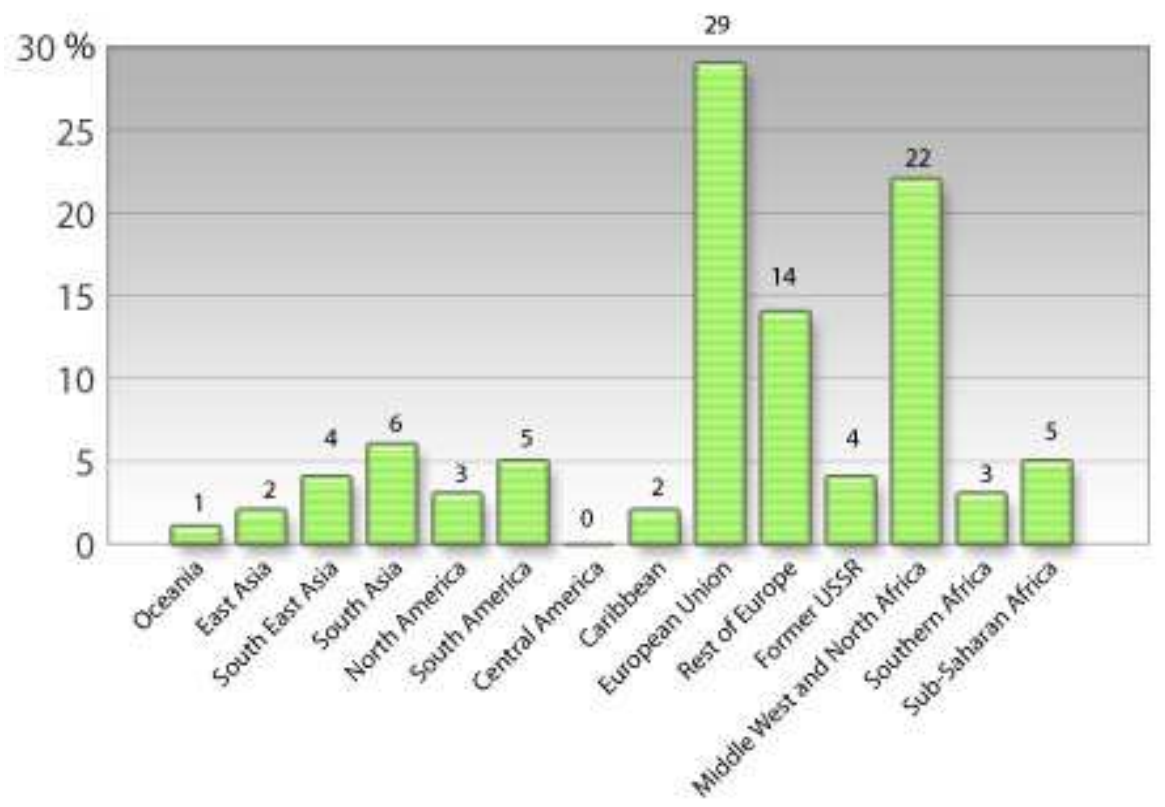

\section{A new social reality, new challenges}

The prevalence of obesity among immigrants depending on education level and the origin of their countries. While immigrants with Hispanic ethnicity appear to exhibit increase in obesity as their stay in the Europe (12-16) becomes longer, Asian and white immigrants do not experience any statistically significant increase.

Another point that is important is the more time has passed since the time of arrival in the new host country, the incidence of obesity is higher (18-22)

Same keys of this fact could be, Counseling on diet and physical activity in the early phase of their arrival may therefore help arrest the growing prevalence of obesity among immigrants. Such counseling is likely to be more effective if directed at low-educated immigrants and on those who arrived at a relatively young age since these two groups are most likely to experience increases in obesity after arrival in Europe.

From another point of view, immigrants from low socioeconomic backgrounds are less likely to have access to quality healthcare (22). They also have limited or no counseling for diet and physical exercise. This research therefore suggests that resources for counseling on diet and physical exercise should be committed to help the most vulnerable populations, e.g. the low educated, those who immigrate when young and among ethnic groups, resources should be channeled toward providing counseling to Latino immigrants (26-30).

A key of Europe healthy will be control the BMI of our children, in special the immigrant children. The number of born of immigrant's families and the rate of immigrant in same countries of Europe will be a great role influence in our more nearest future. 


\section{Summary}

The increase of population in Europe in recent years at the expense of increased immigration is a fact.

These new populations tend to maintain their eating habits but ill adapted to the new reality in which they live: easy and cheap access to food, many high-calorie, reduced physical activity, increased sedentary ...... is called the "syndrome of the new rich."

There is also a human feeling to give the children what the parents have lacked, which often leads to overeating phenomenon of immigrant child population.

\section{Population by citizenship - Foreigners}

Persons - 2010

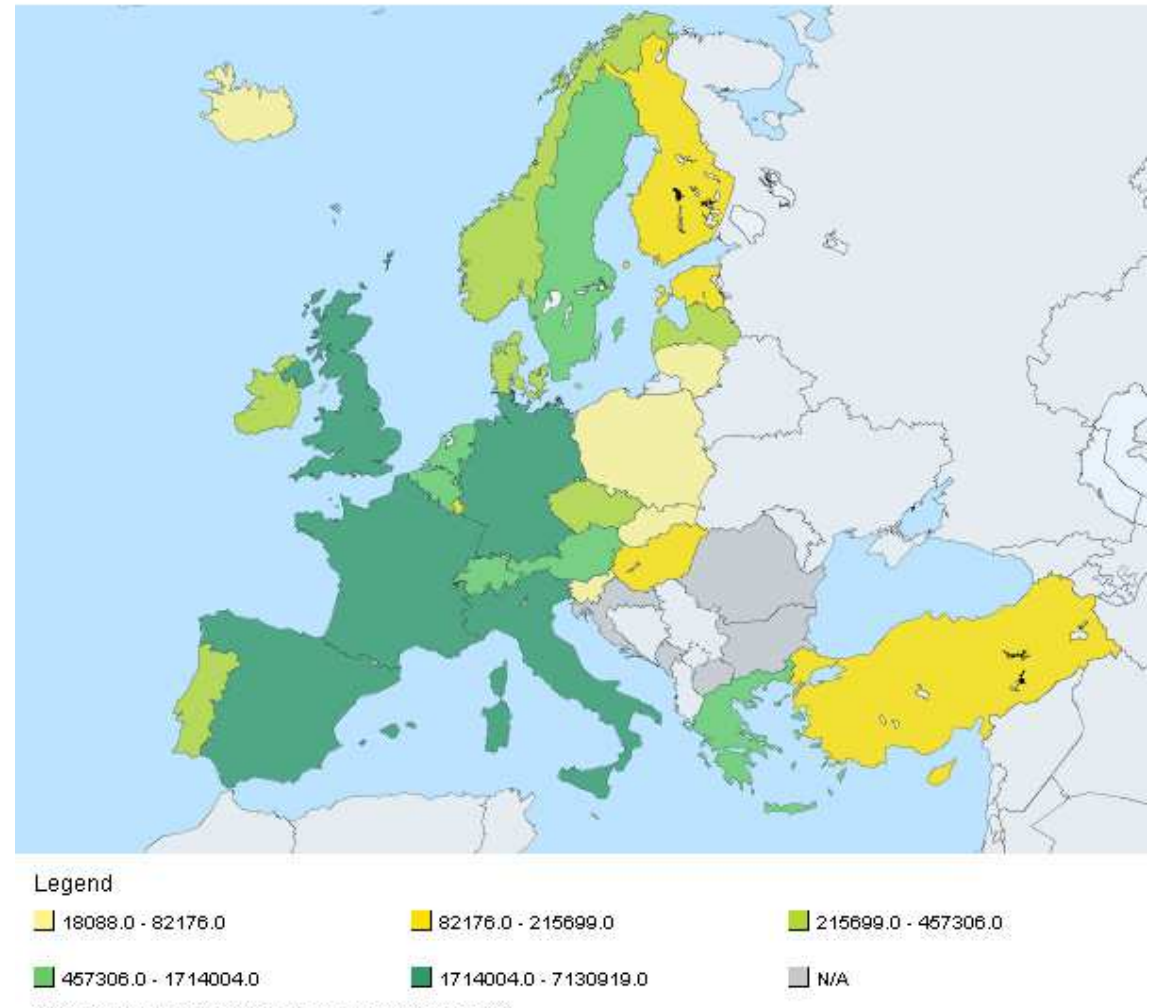

Minimum value: 18088.0 Maximum value: 7130919.0

Source of Data:: Eurostat

On the other hand is the fact of the possibility that part of the immigrant population has a higher rate of "energy-saving genes," a fact that has led to a survival advantage in their countries of origin but a clear disadvantage in the "rich Europe". 
These fact combined with a possible increased susceptibility to the development of metabolic disease is causing an increase in the prevalence of obesity and obesity-related diseases in child and adolescent population of immigrants.

This is a major challenge for the future of European health systems. Coping with new social, economic and adjusting the existing health resources against a disease increasingly pressing, which, to do nothing, will lead to an unprecedented increase in health spending due to metabolic and cardiovascular diseases.

Of the health conscious this problem depends on the current reality obese children, does not become a majority of young adults sick.

\section{List of abbreviations}

BMI: Body mass index

\section{Competing interests}

The author(s) declare that they have no competing interest

\section{References}

[1] World Health Organization: Obesity: Preventing and managing the global epidemic. WHO technical report series. Volume 894. Geneva, WHO; 2000.

[2] World Health Organization: Fifty-seventh world health assembly. Global strategy on diet, physical activity and health. Geneva, 17-22 May. 2004.

[3] Deckelbaum RJ, Williams CL: Childhood obesity: the health issue. Obes Res 2001, 9 Suppl 4:239S-243S.

[4] Reilly JJ, Methven E, McDowell ZC, Hacking B, Alexander D, Stewart L, Kelnar CJ: Health consequences of obesity. Arch Dis Child 2003, 88:748-752.

[5] Must A, Anderson SE: Effects of obesity on morbidity in children and adolescents. Nutr Clin Care 2003, 6:4-12.

[6] Dietz WH: Health consequences of obesity in youth: childhood predictors of adult disease. Pediatrics 1998, 101:518-525.

[7] 7 Dietz WH: Childhood weight affects adult morbidity and mortality. J Nutr 1998, 128:411S-414S.

[8] Must A: Morbidity and mortality associated with elevated body weight in children and adolescents. Am J Clin Nutr 1996, 63:445S-447S.

[9] Lobstein T, Frelut ML: Prevalence of overweight among children in Europe. Obes Rev 2003, 4:195-200.

[10] Krassas GE, Tzotzas T, Tsametis C, Konstantinidis T: Prevalence and trends in overweight and obesity among children and adolescents in Thessaloniki, Greece. J Pediatr Endocrinol Metab 2001, 14 Suppl 5:1319-1326.

[11] Kromeyer-Hauschild K, Zellner K, Jaeger U, Hoyer H: Prevalence of overweight and obesity among school children in Jena (Germany). Int J Obes Relat Metab Disord 1999, 23:1143-1150.

[12] Langnäse K, Mast M, Muller MJ: Social class differences in overweight of prepubertal children in northwest Germany. Int J Obes Relat Metab Disord 2002, 26:566-572. 
[13] Haas JS, Lee LB, Kaplan CP, Sonneborn D, Phillips KA, Liang SY: The association of race, socioeconomic status, and health insurance status with the prevalence of overweight among children and adolescents. Am J Public Health 2003, 93:2105-2110.

[14] Nelson JA, Chiasson MA, Ford V: Childhood overweight in a New York City WIC population. Am J Public Health 2004, 94:458-462.

[15] Ministerium für Schule Jugend und Kinder des Landes Nordrhein- Westfalen: Ausländische und ausgesiedelte Schülerinnen und Schüler, Ausländische Lehrerinnen und Lehrer im Schuljahr 2003/04. 2004, 344:.

[16] Gawrich S: Wie gesund sind unsere Schulanfänger?- Zur Interpretation epidemiologischer Auswertungen der Schuleingangsuntersuchung. Hessisches Ärzteblatt 2004, 2:73-76.

[17] Erb J, Winkler G: Role of nationality in overweight and obesity in preschool children in Germany. Monatsschrift Kinderheilkunde 2004, 152:291-298.

[18] Bauer C, Rosemeier A: A handicap for life - Overweight and obesity in pre-school children in Karlsruhe. Gesundheitswesen 2004, 66:246-250.

[19] Gesundheitsamt der Stadt Dortmund: Die Gesundheit der Schulanfängerinnen und Schulanfänger in Dortmund- Ergebnisse der schulärztlichen Untersuchungen von 1985-1996. 1997, 5:

[20] Delekat D: Zur Gesundheitlichen Lage von Kindern in Berlin- Ergebnisse und Handlungsempfehlungen auf Basis der Einschulungsuntersuchungen 2001.Spezialbericht 2003-2. Berlin, Senatsverwaltung für Gesundheit, Soziales und Verbraucherschutz; 2003.

[21] Kalies H, Lenz J, von Kries R: Prevalence of overweight and obesity and trends in body mass index in German pre-school children, 1982-1997. Int J Obes Relat Metab Disord 2002, 26:1211-1217.

[22] Díez López I, Rodríguez Estévez A Revista Española de Obesidad Vol. 62008 6:280-285

[23] Saxena S, Ambler G, Cole TJ, Majeed A: Ethnic group differences in overweight and obese children and young people in England: cross sectional survey. Arch Dis Child 2004, 89:30-36.

[24] Roville-Sausse F: [Increase during the last 20 years of body mass of children 0 to 4 years of age born to Maghrebian immigrants]. Rev Epidemiol Sante Publique 1999, 47:37-44.

[25] Brussaard JH, Erp-Baart MA, Brants HA, Hulshof KF, Lowik MR: Nutrition and health among migrants in The Netherlands. Public Health Nutr 2001, 4:659-664.

[26] Oner N, Vatansever U, Sari A, Ekuklu E, Guzel A, Karasalihoglu S, Boris NW: Prevalence of underweight, overweight and obesity in Turkish adolescents. Swiss Med Wkly 2004, 134:529-533.

[27] Neovius M, Linne Y, Barkeling B, Rossner S: Discrepancies between classification systems of childhood obesity. Obes Rev 2004, 5:105-114.

[28] Wang Y, Wang JQ: A comparison of international references for the assessment of child and adolescent overweight and obesity in different populations. Eur J Clin Nutr 2002, 56:973-982.

[29] Wang Y, Monteiro C, Popkin BM: Trends of obesity and underweight in older children and adolescents in the United States, Brazil, China, and Russia. Am J Clin Nutr 2002, 75:971-977.

[30] Koziel S, Kolodziej H, Ulijaszek SJ: Parental education, body mass index and prevalence of obesity among 14-year-old boys between 1987 and 1997 in Wroclaw, Poland. Eur J Epidemiol 2000, 16:1163-1167.

[31] Wang Y: Cross-national comparison of childhood obesity: the epidemic and the relationship between obesity and socioeconomic status. Int J Epidemiol 2001, 30:1129-1136. 


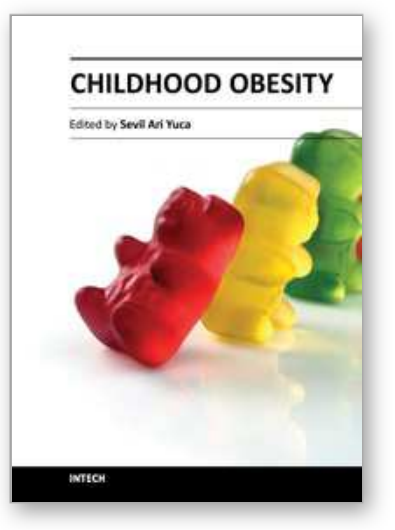

\author{
Childhood Obesity \\ Edited by Dr. Sevil Ari Yuca
}

ISBN 978-953-51-0374-5

Hard cover, 236 pages

Publisher InTech

Published online 28, March, 2012

Published in print edition March, 2012

This book aims to provide readers with a general as well as an advanced overview of the key trends in childhood obesity. Obesity is an illness that occurs due to a combination of genetic, environmental, psychosocial, metabolic and hormonal factors. The prevalence of obesity has shown a great rise both in adults and children in the last 30 years. It is known that one third of children who are obese in childhood and $80 \%$ of adolescents who are obese in their adolescent years continue to be obese later in life. Obesity is an important risk factor in serious illnesses such as heart disease, hyperlipidemia, hyperinsulinemia, hypertension and early atherosclerosis.

\title{
How to reference
}

In order to correctly reference this scholarly work, feel free to copy and paste the following:

I. Díez López and M. Carranza Ferrer (2012). Childhood Inmigration and Obesity - An Emerging Problem, Childhood Obesity, Dr. Sevil Ari Yuca (Ed.), ISBN: 978-953-51-0374-5, InTech, Available from:

http://www.intechopen.com/books/childhood-obesity/childhood-inmigration-and-obesity-an-emerging-problem-

\section{INTECH}

open science | open minds

\section{InTech Europe}

University Campus STeP Ri

Slavka Krautzeka 83/A

51000 Rijeka, Croatia

Phone: +385 (51) 770447

Fax: +385 (51) 686166

www.intechopen.com

\section{InTech China}

Unit 405, Office Block, Hotel Equatorial Shanghai

No.65, Yan An Road (West), Shanghai, 200040, China

中国上海市延安西路65号上海国际贵都大饭店办公楼 405 单元

Phone: +86-21-62489820

Fax: +86-21-62489821 
(C) 2012 The Author(s). Licensee IntechOpen. This is an open access article distributed under the terms of the Creative Commons Attribution 3.0 License, which permits unrestricted use, distribution, and reproduction in any medium, provided the original work is properly cited. 